\title{
Reasons for Failure of Antifungal-lock Therapy with Caspofungin: Need for Higher Concentrations
}

\author{
Kaspofunginle Antifungal Kilit Tekniği Başarııızık Nedenleri: \\ Daha Yüksek Konsantrasyon Ihtiyacı
}

\begin{abstract}
Rana İşgüder¹, Gökhan Ceylan¹, Özlem Sandal1, Ferhat Sarı1, Gamze Gülfidan², Bengü Demirağ3 , Hasan Ağın¹, illker Devrim4
${ }^{1}$ Dr. Behçet Uz Children's Diseases and Surgery Training and Research Hospital, Unit of Pediatric Intensive Care, Izmir, Turkey

2Dr. Behçet Uz Children's Diseases and Surgery Training and Research Hospital, Clinic of Microbiology, Izmir, Turkey

${ }^{3}$ Dr. Behçet Uz Children's Diseases and Surgery Training and Research Hospital, Clinic of Pediatric Hematology and Oncology, izmir, Turkey

${ }^{4}$ Dr. Behçet Uz Children's Diseases and Surgery Training and Research Hospital, Clinic of Pediatric Infectious Disease, Izmir, Turkey
\end{abstract}

\section{Abstract}

Antifungal-lock therapy (AfLT) has arrived as an investigational approach for preventing catheter removal with limited clinical evidence of its efficiency. The principle of AfLT consists of catheter lumen replenishment by a selected antimicrobial agent and then locking it for an alternative treatment to eradicate the microbes embedded in endoluminal biofilms. Herein, we report a pediatric hematology-oncology patient with Candida parapsilosis-related central venous access device infection in which catheter removal was performed despite the systemic and intraluminal caspofungin treatment. For now, we recommend higher doses of caspofungin for AfLT especially in Candida parapsilosis-related catheter infections. Keywords: Antifungal-lock technique, Candida species, caspofungin, catheter

\section{Öz}

Antifungal kilit tekniği (AfKT) kateter çıkarılmasını engellemek amacı ile etkinliği hakkında kısıtlı verinin olduğu bir deneysel yaklaşım olarak karşımıza çıkmaktadır. Bu teknikte endoluminal biyofilmler içine gömülü olan etkenlerin eradike edilmesi için katater lümeni, seçilen antimikrobiyal ajanla doldurularak kapatılır. Burada yoğun bakım servisimizde yatan ve Candida parapsilosis ilişkili santral venöz kateter enfeksiyonu olan bir hematoloji-onkoloji hastasından gerek intraluminal gerekse sistemik kaspofungin tedavisine rağmen kateteri çıkartmak zorunda kalışımızı raporladık. Özellikle Candida parapsilosis ilişkili kateter enfeksiyonlarının AfKT ile tedavi edilebilmesi için daha yüksek dozda kaspofungin kullanılmasını önermekteyiz.

Anahtar Kelimeler: Antifungal kilit tekniği, Candida türleri, kaspofungin, kateter

\section{Introduction}

The incidence of fungal infections in pediatric patients follows the same trend of increase as in adults. ${ }^{1}$ Among them, Candida species have been the dominant type representing the majority of blood stream infections (BSI) and associated catheter-related BSI with a rate of $10 \% .{ }^{2}$ Recent studies have reported increased incidences of other Candida species, especially Candida parapsilosis besides Candida tropicalis and Candida glabrata. ${ }^{3}$ Candida parapsilosis is a major concern since its association with central venous access device (CVAD)related infections has been well demonstrated. ${ }^{3}$ The Infectious Diseases Society of America (IDSA) and European Society for
Clinical Microbiology and Infectious Diseases guidelines on Candida catheter-related BSI recommend systemic antifungal therapy and timely catheter removal. ${ }^{4,5}$ However, catheter removal may not be easily performed in real life. First of all; removal from patients with totally implanted catheters, such as ports, require a surgical procedure. Moreover, patients' co-morbidities, such as severe thrombocytopenia and disseminated intravascular coagulation, could complicate the process. Antifungal-lock therapy (AfLT) is an investigational approach which can be used as salvage therapy for preventing catheter removal. ${ }^{5}$ The principle of AfLT consists of catheter lumen replenishment by a selected antimicrobial agent and 
then locking it for an alternative treatment to eradicate the microbes in endoluminal biofilms. The most promising AfLT include ethanol, amphotericin B or echinocandins. ${ }^{6}$ Among them, Candida parapsilosis requires special considerations, since there were some reports of decreased susceptibility to systemic echinocandins. ${ }^{7}$ The feasibility of caspofungin for AfLT is still an unanswered question for the clinicians. Herein, we report a pediatric hematology-oncology patient with Candida parapsilosis-related central venous access device (CVAD) infection in which the catheter was removed despite systemic and intraluminal caspofungin treatment. Written informed consent was obtained from the parent of the patient.

\section{Case}

A 1.5-year-old boy with pro-B acute lymphoblastic leukemia was transferred to the pediatric intensive care unit (PICU) due to Enterobacter cloacae septicemia, respiratory failure and septic shock. The patient was treated with intravenous meropenem and amikasin. He had a long-term CVAD (port) for 10 months. The white blood count was $900 \mathrm{~mm}^{-3}$, neutrophil count was $150 \mathrm{~mm}^{-3}$, and platelet count was $19000 \mathrm{~mm}^{-3}$. On the $43^{\text {th }}$ day of admission to the PICU, blood cultures, two from peripheral veins and one through ports, revealed Candida parapsilosis growth which was susceptible to caspofungin, and amphotericin B. Since Candida parapsilosis was isolated under liposomal amphotericin B therapy, previous antifungal therapy was ceased and intravenous caspofungin $(70 \mathrm{mg} /$ $\mathrm{m}^{2}$ on the first day and $50 / \mathrm{m}^{2}$ for maintenance therapy) was initiated. The blood cultures from peripheral veins revealed no isolation of Candida parapsilosis on the $4^{\text {th }}$ day of caspofungin therapy, however, consecutive blood cultures revealed Candida parapsilosis isolation. We could not remove the catheter due to the patient's clinical status and absence of any other available vascular access. AfLT with caspofungin was also initiated on the $7^{\text {th }}$ day of intravenous caspofungin. The lock used a portion of $3 \mathrm{~mL}$ solution of $10 \mathrm{mg}$ of caspofungin and $5 \%$ dextrose with 200 units of heparin and placed lines for $12 \mathrm{~h}$. AfLT was repeated at every 12 hours and the catheter blood culture was taken before each procedure as described before. $^{8}$ On the $14^{\text {th }}$ day of AfLT, since no negative culture could be achieved with AfLT, the port was removed.

\section{Discussion}

There is currently no consensus on the treatment of invasive Candida parapsilosis infections, although the therapeutic approach typically includes the extraction of any removable foreign bodies and the administration of systemic antifungals. ${ }^{4}$ The IDSA guidelines list amphotericin B, fluconazole, and caspofungin as therapeutic options for the treatment of candidemia. ${ }^{4}$ The reports of successful AfLTs have been reported more and more frequently with different agents, however, we had experienced a treatment failure which led to removal of the catheter despite intraluminal and systemic caspofungin treatment.

Biofilms are surface-associated communities of microorganisms within an extracellular matrix and are the most prevalent type of microbial growth. ${ }^{9}$ Although Candida parapsilosis has been reported to produce quantitatively and structurally less complex biofilm than Candida albicans; Candida parapsilosis biofilms can occur on medical devices, including central venous catheter (CVC) and peripheral venous catheters. ${ }^{10}$ The formation of biofilms is important for the failure of AfLT; since it is one of the major virulence factors resulting in significant resistance to antifungal therapy by limiting the penetration of substances through the matrix and protecting cells from host immune responses. There are extensive data demonstrating the resistance of Candida species in biofilms to antimycotic drugs. ${ }^{11}$

Therapeutic levels of echinocandins can inhibit metabolic activities of Candida parapsilosis biofilms ${ }^{9}$, and lipid formulations of amphotericin B have shown activity against Candida parapsilosis biofilm. ${ }^{9}$ However, in vitro studies with high-dose amphotericin B usage demonstrated that biofilms of Candida parapsilosis were inhibited to a lesser extent compared to Candida albicans and Candida glabrata.

Devrim et al. ${ }^{12}$ published an article in 2016 and they pointed out that 15 of 41 patients with Candida parapsilosis blood stream infection, who had CVC, were treated with caspofungin without the need for catheter removal. However, caspofungin was not used in lock therapy. It was used systematically in that study.

There are limited reports which had focused on caspofungin and its concentration for intraluminal usage. Thus, the optimal concentration has not been determined yet. Previous reports including in vitro studies have reported caspofungin usage as a wide spectrum of concentration ranging from $0.00025 \mathrm{mg} / \mathrm{lt}$ to $25 \mathrm{mg} / \mathrm{lt}$ for a wide spectrum of duration of therapy ranging from 6 hours to 48 hours. ${ }^{13,14}$ However, only one report is available for the intraluminal caspofungin therapy with a dosage of $3.33 \mathrm{mg} / \mathrm{mL}$ in a 9-year-old child for the treatment of Candida lipolytica fungemia-associated catheter infections. ${ }^{9}$ In this report, the negative culture was achieved after the fourth day, however, we could not rescue the catheter despite 14 days of intraluminal therapy with caspofungin at the same dose. This could be due to the decreased susceptibility to caspofungin since caspofungin minimal inhibitory concentration (MIC) for Candida parapsilosis are higher than those for other Candida species, with average $\mathrm{MIC}_{50}$ and $\mathrm{MIC}_{90}$ values ranging between 0.85 
and $2 \mathrm{~g} / \mathrm{mL}$ and 2 and $2.33 \mathrm{~g} / \mathrm{mL}$, respectively. ${ }^{15}$ According to our experience; higher concentrations of caspofungin might be required for AfLT for Candida parapsilosis.

Since there is inadequate clinical data for forming the base for specific recommendations for AfLT in the management of catheter-related infections and lack of standardization of the dosage, duration and intraluminal time spent; randomized clinical trials are essential. There should be further studies exploring the appropriate caspofungin dose for AfLT in catheter infections associated with Candida parapsilosis.

\section{Ethics}

Informed Consent: Written informed consent was obtained from the parent of the patient.

Peer-review: Externally peer-reviewed.

\section{Authorship Contributions}

Surgical and Medical Practices: G.C., Ö.S., F.S., Concept: G.C., F.S., Design: H.A., i.D., Data Collection or Processing: R.i., Ö.S., Analysis or Interpretation: H.A., I.D., B.D., Literature Search: G.G., G.C., Writing: G.C., R.i.

Conflict of Interest: No conflict of interest was declared by the authors.

Financial Disclosure: The authors declared that this study received no financial support.

\section{References}

1. Filioti J, Spiroglou K, Panteliadis CP, Roilides E. Invasive candidiasis in pediatric intensive care patients: epidemiology, risk factors, management, and outcome. Intensive Care Med. 2007;33:127283.

2. Kojic EM, Darouiche RO. Candida infections of medical devices. Clin Microbiol Rev. 2004;17:255-67.

3. Girmenia C, Martino P, De Bernardis F, Gentile G, Boccanera M, et al. Rising incidence of Candida parapsilosis fungemia in patients with hematologic malignancies: clinical aspects, predisposing factors, and differential pathogenicity of the causative strains. Clin Infect Dis. 1996;23:506-14.

4. Pappas PG, Kauffman CA, Andes D, Benjamin DK Jr, Calandra TF, et al. Clinical practice guidelines for the management of candidiasis: 2009 update by the Infectious Diseases Society of America. Clin Infect Dis. 2009;48:503-35.

5. Hope WW, Castagnola E, Groll AH, Roilides E, Akova M, et al. ESCMID guideline for the diagnosis and management of Candida diseases 2012: prevention and management of invasive infections in neonates and children caused by Candida spp. Clin Microbiol Infect. 2012;18:38-52.

6. Walraven CJ, Lee SA. Antifungal lock therapy. Antimicrob Agents Chemother. 2013;57:1-8.

7. Beyda ND, Lewis RE, Garey KW. Echinocandin resistance in Candida species: mechanisms of reduced susceptibility and therapeutic approaches. Ann Pharmacother. 2012;46:1086-96.

8. Ozdemir H, Karbuz A, Ciftçi E, Dinçaslan HU, Ince E, et al. Successful treatment of central venous catheter infection due to Candida lipolytica by caspofungin-lock therapy. Mycoses. 2011;54:647-9.

9. Kuhn DM, George T, Chandra J, Mukherjee PK, Ghannoum MA. Antifungal susceptibility of Candida biofilms: unique efficacy of amphotericin B lipid formulations and echinocandins. Antimicrob Agents Chemother. 2002;46:1773-80.

10. Ramage G, Martínez JP, Lopez-Ribot JL. Candida biofilms on implanted biomaterials: a clinically significant problem. FEMS Yeast Res. 2006;6:979-86.

11. d'Enfert C. Biofilms and their role in the resistance of pathogenic Candida to antifungal agents. Curr Drug Targets. 2006;7:465-70.

12. Devrim I, İşgüder R, Ağın H, Ceylan G, Ayhan Y, et al. Outcome of Candida Parapsilosis Complex Infections Treated with Caspofungin in Children. Mediterr J Hematol Infect Dis. 2016;8:e2016042.

13. Miceli MH, Bernardo SM, Lee SA. In vitro analysis of the occurrence of a paradoxical effect with different echinocandins and Candida albicans biofilms. Int J Antimicrob Agents. 2009;34:500-2.

14. Ku TS, Bernardo SM, Lee SA. In vitro assessment of the antifungal and paradoxical activity of different echinocandins against Candida tropicalis biofilms. J Med Microbiol. 2011;60:1708-10.

15. Trofa D, Gacser A, Nosanchuk JD. Candida parapsilosis, an emerging fungal pathogen. Clin Microbiol Rev. 2008;21:606-25. 